\title{
Pengaruh Pemberian Deep Neck Flexor Muscle Activation Terhadap Nyeri Leher: Critical Review \\ ${ }^{1}$ Yusria Apriliani, ${ }^{2}$ Arif Pristianto, ${ }^{3}$ Wijianto, ${ }^{4}$ Wahyuni
}

Program Studi Fisioterapi, Fakultas Ilmu Kesehatan, Universitas Muhammadiyah SurakartaJalan Ahmad Yani, Pabelan, Kartasura, Surakarta, Jawa Tengah Indonesia 57162

Email: ums@ums.ac.id

\begin{abstract}
ABSTRAK
Latar belakang: Nyeri leher menyebabkan penurunan kekuatan otot, dan penurunan daya tahan otot sternocleidomastoid dan deep cervical flexor. Hal itu menyebabkan disfungsi mekanis dan nyeri kronis. Aktivasi deep cervical flexion muscle merupakan bentuk latihan penguatan pada otot, mampu memberikan efek yang signifikan dalam menurunkan nyeri leher. Tujuan: penelitian ini bertujuan untuk mengetahui pengaruh pemberian deep neck flexor muscle activation pada nyeri leher Metode: metode penelitian critical review dan desain studi randomized controlled trial menggunakan mesin pencarian literatur seperti Pubmed Central (PMC) dan Google Scholar, kemudian dilanjutkan dengan mengidentifikasi jenis Quartile (Q1-3) menggunakan Scimago Journal and Country Rank (SJR) dan penilaian dengan PEDro scale Hasil: Sebanyak 9 artikel yang digunakan sebagai landasan penelitian, pada DCF menunjukan penurunan nyeri dengan VAS. Kesimpulannya penelitian menunjukkan adanya pengaruh yang signifikan pada latihan deep neck flexor muscle activation terhadap penurunan nyeri leher pada kondisi nyeri leher kronis maupun non spesifik. Pemberian deep neck flexor muscle activation yang terdiri dari craniocervical flexion, dan cervical stabilizating exercise. Latihan ini dilakukan dengan mendorong kepala kearah belakang dengan menjaga posisi kepala tetap lurus dan diberikan berupa tahanan hingga waktu yang sudah ditentukan
\end{abstract}

Kata kunci: nyeri leher, muscle activation, DFC

\section{ABSTRACT}

Background: Neck pain causes decreased muscle strength, and decreased endurance of the sternocleidomastoid and deep cervical flexor muscles. It causes mechanical dysfunction and chronic pain. Activation of deep cervical flexion muscle is a form of strengthening exercises for muscles that can have a significant effect in reducing neck pain. Objective: This study aims to determine the effect of deep neck flexor muscle activation on neck pain. Methods: The method uses critical review and randomized controlled trial study design using literature search engines such as Pubmed Central (PMC) and Google Scholar, then finds the type of Quartile (Q1-3) using the Scimago Journal and Country Rank (SJR) and Assessment with the PEDro scale. Results: 9 articles were obtained which were used as the basis of the research. The DCF group showed pain relief with VAS. Conclusion: the study shows that there is a significant effect on deep neck flexor muscle activation exercise on reducing neck pain in chronic and non-specific neck pain conditions. Giving deep neck flexor muscle activation consisting of craniocervical flexion and cervical stabilization exercise. This exercise is done by pushing the head back by keeping the head in a straight position and given in the form of resistance until a predetermined time

Keywords: neck pain, muscle activation, DFC 
Apriliani Y; Pristianto A; Wijianto \& Wahyuni

Fisiomu.2021 Vol 2(3): 133-149

DOI: $10.23917 /$ fisiomu.v1i3.15194

\section{Pendahuluan}

Leher merupakan bagian atas anggota tubuh yang berfungsi menopang kepala dan bagian tulang belakang. Leher memiliki struktur yang kompleks dan sangat rentan terhadap iritasi maupun gangguan muskuloskeletal (Yuliana \& Kushartanti, 2019). Masalah pada leher dapat memberikan dampak buruk pada fisik, psikologis dan aspek sosial penderitanya (Suvarnnato et al., 2019). Nyeri leher merupakan salah satu keluhan muskuloskeletal yang paling umum terjadi. Menurut WHO nyeri leher menempati urutan ke-4 sebagai penyumbang kecacatan global terbesar. Populasi 30-50\% mengalami nyeri leher setiap tahunnya, dan setiap dua dari tiga orang mengalami nyeri leher selama hidup (Cheung et al., 2013).

Menjaga kekuatan otot-otot deep cervical flexor sangat penting untuk mengontrol postur dan stabilitas leher (Kim \& Kwag, 2016).

Defisiensi aktivitas deep cervical muscle pada tulang belakang leher dapat menyebabkan kontrol yang buruk terhadap gerakan sendi, mikrotrauma berulang, dan pada akhirnya menimbulkan nyeri (Suvarnnato et al., 2019). Sekitar 59\% pasien dengan nyeri leher dirujuk ke fisioterapis atau manual terapis (Graaf \& Schmi, 2012).

Nyeri leher menyebabkan penurunan kekuatan otot, dan penurunan daya tahan otot sternocleidomastoid dan deep cervical flexor. Masalah kecil pada leher akibat postur tubuh dan kontraksi otot yang tiba-tiba, membuat otot mengalami penyusutan dan tidak dapat digunakan. Hal itu menyebabkan disfungsi mekanis dan nyeri kronis. Deep cervical flexor terdiri dari otot longus colli dan otot longus capitis, yang berperan penting dalam menjaga kontrol postur dan kestabilan leher serta terdapat otot upper trapezius diteliti sebagai otot yang berpengaruh terhadap kurva dari region cervical (Prasana et al., 2018).

Beberapa metode latihan yang digunakan oleh fisioterapis yaitu, mobilisasi sendi, peregangan, latihan penguatan isometrik, latihan ketahanan, dan latihan proprioseptif tergantung pada kondisi pasien dan teori yang digunakan oleh fisioterapis (Hande \& Agrawal, 2017). Dari penelitian sebelumnya, menurut Jull et al (2009) deep cervical muscle activation tidak menunjukkan penurunan nyeri secara signifikan. Sedangkan pada penelitian Kim Jin Young (2016) aktivasi deep cervical flexion muscle merupakan bentuk latihan penguatan pada otot, mampu memberikan efek yang signifikan dalam menurunkan nyeri leher. Karena terdapat hasil yang kontradiktif pada penelitian sebelumnya maka penulis tertarik untuk mengkaji beberapa literatur sehingga dapat dihasilkan kesimpulan.

\section{Metode Penelitian}

Critical review merupakan metode penelitian dengan cara analisis dan evaluasi dari sebuah buku, artikel, jurnal atau media lainnya. Tujuan penulisan critical review yaitu untuk 
Apriliani Y; Pristianto A; Wijianto \& Wahyuni

Fisiomu.2021 Vol 2(3): 133-149

DOI: $10.23917 /$ fisiomu.v1i3.15194

mengungkapkan suatu sudut pandang penulis tentang informasi yang diperoleh. Pencarian data dilakukan dengan mengidentifikasi metode uji coba terkontrol secara acak atau Randomized Controlled Trial yang ditulis dalam bahasa Inggris menggunakan mesin pencarian literatur seperti Pubmed Central (PMC) dan Google Scholar dengan menggunakan kata kunci "training" atau "exercise" kemudian digabungkan dengan beberapa kata kunci lainnya. Kombinasi kata kunci seperti "Deep cervical flexor training or exercise"; "Craniocervical flexion training or exercise"; "Endurance training or exercise AND neck pain"; "Stabilization training or exercise AND neck pain".

Setelah mendapat artikel kemudian dilanjutkan dengan mengidentifikasi jenis Quartile (Q1-3) dari artikel yang ditemukan, menggunakan mesin pencarian Scimago Journal and Country Rank (SJR). Pengumpulan data dilakukan dengan kriteria inklusi: artikel ilmiah berbahasa Inggris yang diterbitkan pada tahun 2010-2021, jenis penelitian artikel RCT, standar PICO yang dijadikan base dalam review ini yaitu population disini adalah penderita gangguan nyeri leher usia 18-65 tahun, intervention yaitu Deep neck flexor training, comparison dengan satu atau dua latihan seperti general neck exercise, propioceptive training, core stability exercise atau dengan kelompok kontrol tanpa intervensi, dan outcome dengan VAS.
Kemudian dilanjutkan dengan tahapan appraisal ini yaitu teknik ceklis pada skala PEDro. Skala PEDro adalah alat yang digunakan untuk mengukur kualitas dari intervensi Fisioterapi yang diberikan, dalam jenis penelitian Randomized Controlled Trials (RCT). Terdapat 11 poin yang diukur dalam skala ini, dengan cara penilaian dikatakan yes dengan nilai 1 poin jika terdapat dalam artikel, dan no dengan nilai 0 jika tidak terdapat dalam artikel tersebut.

\section{Hasil}

Desain studi randomized controlled trial merupakan studi yang paling kuat digunakan untuk mengevaluasi intervensi yang digunakan untuk menunjukkan bahwa intervensi yang digunakan benar-benar layak. RCT atau telah dianggap sebagai bukti ilmiah yang paling terpecaya dalam perawatan kesehatan karena menghilangkan kausalitas palsu dan bias.

Alur studi pencarian artikel, dengan total pencarian data 547 artikel menggunakan basis pencarian Pubmed Central (PMC) dan Google Scholar, terdapat 9 artikel yang akan di review. Dari kesembilan artikel yang telah terpilih sebagai landasan dalam studi ini, semuanya telah dilakukan pengecekan Quartile menggunakan Scimago Journal and Country Rank (SJR), dan penilaian ukuran valid dari kualitas metodologi uji klinis menggunakan PEDro scale. Tahapan pecarian artikel beserta pengecualian artikel dapat dilihat pada gambar 1 
Apriliani Y; Pristianto A; Wijianto \& Wahyuni

Fisiomu.2021 Vol 2(3): 133-149

DOI: $10.23917 /$ fisiomu.v1i3.15194

Kesembilan artikel memiliki kriteria

Artikel studi

diidentifikasi dari

pencarian database $(\mathrm{n}=547)$

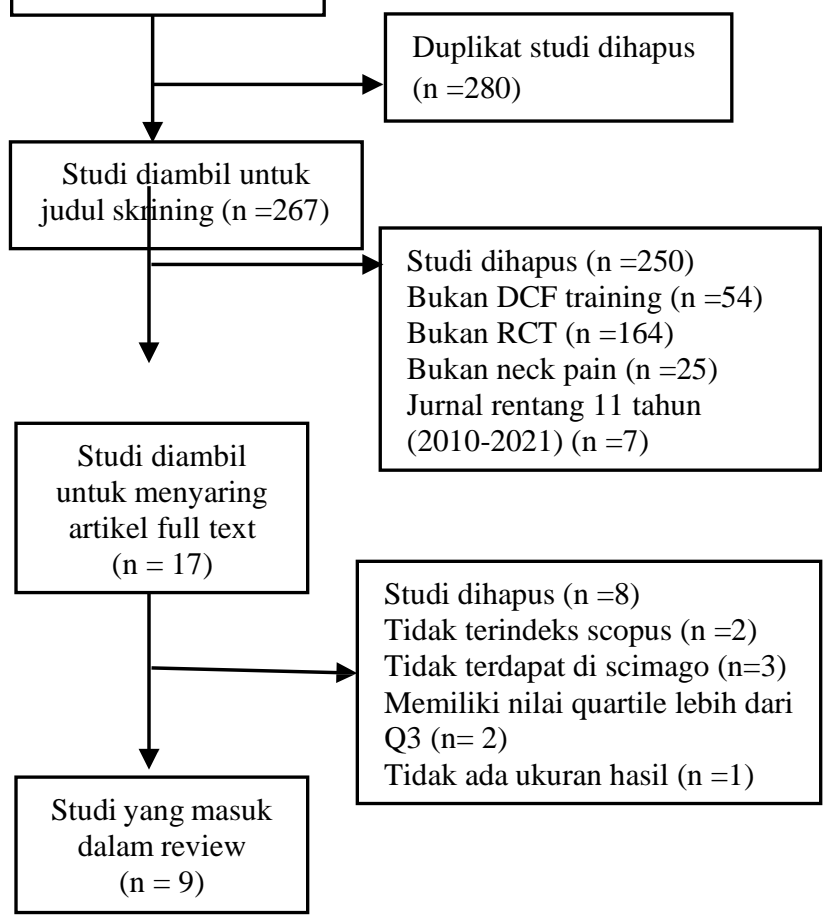

Gambar 1 Pencarian artikel

Setelah dilakukan pengecekan Quartile dan penilaian skala PEDro, didapatkan hasil bahwa empat artikel memiliki nilai Q3, tiga artikel memiliki nilai Q2, dan dua artikel memiliki nilai Q1. Semua artikel memiliki kriteria kelayakan atau (eligibility criteria), dan menggunakan alokasi secara acak (random allocated) kepada subjek. Delapan artikel melakukan alokasi tersembunyi (concealed allocation) dan satu artikel tidak menyatakan alokasi tersembunyi. ukuran keparahan dan setidaknya satu hasil utama (baseline comparability) sebagai perbandingan atau tolak ukur hasil sebelum dan sesudah pemberian intervensi, satu artikel tidak menyatakan blind subject, dan delapan artikel menyatakan blind subject. Dua artikel menyatakan blind therapist, sisanya tujuh tidak menyatakan.

Sedangkan pada blind assessor, lima artikel menyatakan tidak menggunakan, dan empat artikel menggunakan teknik blind assessor. Selanjutnya, terdapat delapan artikel dalam penelitian yang $>85 \%$ subjek dalam penelitian dan satu artikel tidak memenuhi kriteria. Tujuh artikel menyatakan semua subjek menerima perawatan sesuai dengan alokasi subjek tersebut berada, dan tiga artikel tidak menyatakan (intention-to-treat analysis), dan dari sembilan artikel terpilih semua memiliki item perbandingan antar kelompok (betweengroup comparison) dan titik ukur dan varibilitas (point estimates and variability).

Dari keseluruhan artikel, disimpulkan total nilai appraisal yang didapat dari pengukuran skala PEDdro, yaitu terdapat satu artikel dengan total skor 6/10 yaitu baik, dua artikel dengan skor 7/10 yaitu baik, tiga skor $8 / 10$ bernilai baik, dua skor $9 / 10$ yaitu sangat baik, dan satu artikel dengan nilai sempurna $10 / 10$ bernilai sangat baik. 
Tabel 1. Review artikel

\begin{tabular}{lllllll}
\hline Penulis & Population & Intervention & Comparison & Hasil & Kesimpulan \\
\hline (Borisut & Subjek 100 wanita & group (1) latihan group (4) & Nyeri dapat dikurangi Hasil & penelitian \\
et al., & yang memiliki & kekuatan-ketahanan, kelompok & dengan latihan kekuatan merekomendasi penggunaan \\
$2013)$ & riwayat nyeri leher & group (2) latihan kontrol & dan latihan ketahanan. latihan strength endurance \\
& intermiten terkait fleksi craniocervical, & & Selain itu, latihan umum dan latihan cranio-cervical \\
& pekerjaan & group (3) kombinasi & seperti latihan kekuatan flexion (CCF) pada otot \\
& & latihan kekuatan- & dan ketahanan, serta servikal sebagai intervensi \\
& & ketahanan dan fleksi & & latihan khusus seperti pengobatan bagi pasien nyeri \\
& & craniocervical & & fleksi kranio-servikal pada leher kronis.
\end{tabular}

otot fleksor dalam telah terbukti mengurangi gejala nyeri leher

(Khan 68 pasien nyeri leher Isometric Neck General

et al., non-spesifik kronis Exercise Group direkrut dari klinik

Alain Poly \&

Institute of Physical

Medicine \&

Rehabilitation Dow

University of Health

Sciences Karachi

(Lee \& Subjek sebanyak 46

Kim, pasien laki laki dan

2016) perempuan usia 1860 tahun dengan latihan craniocervical nyeri leher kronis
Neck

Exercise

Group

Kelompok

kontrol

Grup C

(latihan

mandiri

Grup B (latihan ROM aktif) craniocervical fleksor dalam)
Isometrik latihan telah Latihan isometrik dan umum terbukti secara statistik dan efektif dalam mengurangi klinis lebih efektif dalam nyeri leher, meningkatkan semua ukuran fungsi dan meningkatkan dibandingkan dengan berbagai gerakan leher.

latihan umum.

Dalam penelitian ini, nyeri leher berkurang secara signifikan lebih besar di grup A ( 3,78 poin VAS $)$ dan B (2,64 poin VAS), daripada di grup $\mathrm{C}$. manipulasi

toraks dikombinasikan dengan pelatihan DCF menghasilkan pengurangan nyeri yang lebih besar, peningkatan kekuatan dan daya tahan otot, ROM, dan NDI, dibandingkan olahraga saja pada pasien dengan nyeri leher kronis. Tidak ada efek samping yang dilaporkan oleh salah satu peserta selama masa studi. 
Tabel 1. Review artikel

\begin{tabular}{|c|c|c|c|c|c|}
\hline Penulis & Population & Intervention & Comparison & Hasil & Kesimpulan \\
\hline $\begin{array}{l}\text { (Bobos et } \\
\text { al., 2016) }\end{array}$ & $\begin{array}{l}\text { Pasien laki-laki dan } \\
\text { perempuan berusia } \\
\text { antara } 18-65 \text { tahun } \\
\text { dengan nyeri leher } \\
\text { kronis idiopatik } \\
\text { dipilih melalui } \\
\text { pemberitahuan } \\
\text { iklan di rumah sakit } \\
\text { di Achaia, Yunani. }\end{array}$ & $\begin{array}{lrr}\text { Kelompok A adalah } \\
\text { kelompok fleksor } \\
\text { leher dalam dan } \\
\text { kelompok B otot } \\
\text { superfisial. }\end{array}$ & $\begin{array}{l}\text { kelompok } \\
\text { ketiga } \\
\text { adalah } \\
\text { kelompok } \\
\text { pembimbin } \\
\text { g (kontrol). }\end{array}$ & $\begin{array}{l}\text { Hasil menunjukkan bahwa } \\
\text { program latihan progresif } \\
\text { pada otot fleksor leher } \\
\text { dalam dan superfisial yang } \\
\text { berlangsung selama } 7 \\
\text { minggu sudah cukup } \\
\text { mengurangi kecacatan dan } \\
\text { nyeri leher. }\end{array}$ & $\begin{array}{l}\text { Hasil penelitian ini } \\
\text { menunjukkan progresif yang } \\
\text { spesifik program pelatihan } \\
\text { yang menargetkan otot yang } \\
\text { deep dan superfisial mampu } \\
\text { mengurangi rasa sakit dan } \\
\text { kecacatan. }\end{array}$ \\
\hline $\begin{array}{l}\text { (Izquierd } \\
\text { o et al., } \\
\text { 2016) }\end{array}$ & $\begin{array}{l}28 \text { relawan laki laki } \\
\text { dan permpuan usia } \\
18-55 \text { tahun dengan } \\
\text { nyeri leher non } \\
\text { spesifik melalui } \\
\text { iklan selama } \\
\text { periode Januari } \\
\text { hingga Juni } 2014 .\end{array}$ & $\begin{array}{l}\text { Cranio-cervical } \\
\text { flexion training }\end{array}$ & $\begin{array}{l}\text { Propriocept- } \\
\text { ive training }\end{array}$ & $\begin{array}{l}\text { Kedua } \\
\text { menunjukkan penurunan } \\
\text { nyeri saat istirahat dan } \\
\text { kecacatan pada } 2 \text { bulan, } \\
\text { tetapi ini juga tidak } \\
\text { berbeda antar kelompok } \\
\text { (p> 0,05). Sensitivitas } \\
\text { nyeri tekanan tidak berubah } \\
\text { untuk kedua kelompok. }\end{array}$ & \begin{tabular}{lrr} 
Kedua pelatihan & fleksi \\
craniocervical & spesifik dan \\
pelatihan & propriosepsi \\
memiliki & efek & yang \\
sebanding & Hasil & ini \\
menunjukkan & \multicolumn{2}{c}{ bahwa } \\
pelatihan & proprioception \\
memberikan efek positif pada \\
fungsi fleksor
\end{tabular} \\
\hline $\begin{array}{l}\text { (Ghaderi } \\
\text { et al., } \\
2016)\end{array}$ & $\begin{array}{l}40 \text { pasien pria dan } \\
\text { wanita dengan } \\
\text { nyeri leher kronis } \\
\text { direkrut di Klinik } \\
\text { fisioterapi dari } \\
\text { Fakultas } \\
\text { Rehabilitasi Ilmu } \\
\text { Kedokteran } \\
\text { Universitas Tabriz. }\end{array}$ & $\begin{array}{l}\text { Stabilization exercise } \\
\text { group }\end{array}$ & $\begin{array}{l}\text { Routine } \\
\text { exercise } \\
\text { group }\end{array}$ & $\begin{array}{lrr}\begin{array}{l}\text { Daya tahan } \\
\text { kelompok }\end{array} & \begin{array}{r}\text { otot } \\
\text { stabilisasi } \\
\text { meningkat }\end{array} \\
\text { signifikan dibandingkan } \\
\text { dengan rutinitas (P } \\
<0 / 001) \text { Juga aktivitas } \\
\text { EMG otot SCM, AS dan } \\
\text { SC secara signifikan } \\
\text { menurun pada kelompok } \\
\text { stabilisasi dibandingkan } \\
\text { dengan rutinitas }(\mathrm{P}<0 / 001)\end{array}$ & $\begin{array}{l}\text { Hasil menunjukkan } \\
\text { penurunan nyeri dan } \\
\text { kecacatan yang signifikan } \\
\text { pada kedua kelompok setelah } \\
\text { intervensi. }\end{array}$ \\
\hline
\end{tabular}




\begin{tabular}{|c|c|c|c|c|c|}
\hline Penulis & Population & Intervention & Comparison & Hasil & Kesimpulan \\
\hline $\begin{array}{l}\text { (Chung } \\
\& \\
\text { Jeong, } \\
\text { 2018) }\end{array}$ & $\begin{array}{lr}\text { Pasien rawat } \\
\text { inap atau jalan } \\
\text { dengan riwayat } \\
\text { CNP non } \\
\text { spesifik lebih } \\
\text { dari } 3 \text { bulan yang } \\
\text { sedang menjalani } \\
\text { perawatan di } \\
\text { pusat rehabilitasi } \\
\text { rumah sakit } \\
\text { universitas yang } \\
\text { terletak di daerah } \\
\text { metropolitan } \\
\text { Seoul di Korea } \\
\text { Selatan sebanyak }\end{array}$ & $\begin{array}{l}\text { Craniocervical } \\
\text { flexion dan } \\
\text { neck isometric } \\
\text { exercise }\end{array}$ & $\begin{array}{l}\text { Kelompok } \\
\text { eksperimen } \\
\text { (CFE) dan } \\
\text { kontrol } \\
\text { (NIE }\end{array}$ & $\begin{array}{l}\text { Program CFE dan NIE selama } \\
\text { delapan minggu menghasilkan } \\
\text { penurunan rasa sakit dan } \\
\text { kecacatan yang dirasakan pada } \\
\text { NDI. CFE bermanfaat untuk } \\
\text { meningkatkan atau } \\
\text { memulihkan lordosis cervical, } \\
\text { ketahanan otot fleksor cervical } \\
\text { bagian dalam, dan ACROM } \\
\text { ketiga bidang dibandingkan } \\
\text { dengan program pelatihan } \\
\text { ulang otot NIE. }\end{array}$ & $\begin{array}{l}\text { Hasil dari penelitian yaitu, } \\
\text { kedua kelompok } \\
\text { menunjukkan penurunan } \\
\text { yang signifikan pada VAS } \\
\text { dan penurunan NDI dan } \\
\text { peningktana ketahan otot } \\
\text { setelah tiap intervensi. }\end{array}$ \\
\hline $\begin{array}{l}\text { (Suvarn } \\
\text { nato } e t \\
\text { al., } \\
\text { 2019) }\end{array}$ & $\begin{array}{lr}54 \text { peserta } & \text { pria } \\
\text { dan } & \text { wanita } \\
\text { dengan } & \text { nyeri } \\
\text { leher mekank } \\
\text { kronis usia } 18-60 \\
\text { tahun direkrut } \\
\text { untuk penelitian }\end{array}$ & $\begin{array}{l}\text { Semispinalis } \\
\text { cervicis-training } \\
\text { group dan Deep } \\
\text { cervical flexor } \\
\text { training group }\end{array}$ & $\begin{array}{l}\text { Kelompok } \\
\text { kontrol } \\
\text { (perawatan } \\
\text { biasa)) }\end{array}$ & $\begin{array}{l}\text { Hasil penelitian menunjukkan } \\
\text { bahwa } 6 \text { minggu latihan pada } \\
\text { kedua kelompok senam dapat } \\
\text { meningkatkan disabilitas leher, } \\
\text { penurunan intensitas nyeri, sudut } \\
\mathrm{CV} \text {, dan kekuatan otot leher pada } \\
\text { leher mekanik kronis. }\end{array}$ & $\begin{array}{l}\text { Latihan khusus dengan } \\
\text { fokus pada otot serviks } \\
\text { bagian dalam merupakan } \\
\text { intervensi penting untuk } \\
\text { mengobati pasien dengan } \\
\text { nyeri leher mekanis kronis. } \\
\text { Latihan olah raga harus }\end{array}$ \\
\hline $\begin{array}{l}\text { (Rajala } \\
\text { xmi et } \\
\text { al., } \\
2020)\end{array}$ & $\begin{array}{l}40 \text { sampel di } \\
\text { rekrut dari OPD } \\
\text { fisioterapi di } \\
\text { A.C.S. perguruan } \\
\text { tinggi kedokteran } \\
\text { dan rumah sakit. }\end{array}$ & $\begin{array}{l}\text { Kelompok } \quad \text { A } \\
\text { menerima neck } \\
\text { stability exercise }\end{array}$ & $\begin{array}{l}\text { Kelompok } \\
\text { B menerima } \\
\text { neck } \\
\text { stability dan } \\
\text { core } \\
\text { stability } \\
\text { exercises }\end{array}$ & $\begin{array}{l}\text { Pada perbandingan nilai rata- } \\
\text { rata Grup A \& Grup B pada } \\
\text { VAS dan NDI Grup B (latihan } \\
\text { stabilitas leher dengan latihan } \\
\text { stabilitas inti) menunjukkan } \\
\text { nilai post-test } 3,5 \text { dan } 33,4 \\
\text { yang lebih efektif daripada } \\
\text { Grup A (latihan stabilitas } \\
\text { leher) } 5.3 \text { dan } 45,2 \text {. }\end{array}$ & $\begin{array}{l}\text { kekuatan dan daya tahan } \\
\text { otot DCF berkurang pada } \\
\text { individu yang menderita } \\
\text { nyeri leher. Selain itu, } \\
\text { mengaktifkan kembali otot } \\
\text { DCF dan reorganisasi } \\
\text { kontrol motorik dan } \\
\text { normalisasi tingkat otot } \\
\text { superfisial pada nyeri leher } \\
\text { menghasilkan hasil klinis } \\
\text { yang lebih baik }\end{array}$ \\
\hline
\end{tabular}


Apriliani Y; Pristianto A; Wijianto \& Wahyuni

Fisiomu.2021 Vol 2(3): 133-149

DOI: $10.23917 /$ fisiomu.v1i3.15194

\section{Pembahasan}

Pemberian deep neck flexor muscle activation yang terdiri dari craniocervical flexion, dan cervical stabilizating exercise masing-masing digunakan untuk melatih dan mengaktivasi otot deep cervical, seperti longus colli, longus capitis, dan anterior restus capitis yang merupakan otot untuk gerakan fleksi leher (Lindstrom, 2013).

Deep cervical flexor berperan sebagai fungsi utama postural dalam menopang dan meluruskan cervical lordosis. Otot-otot di tulang cervical cenderung melemah dikarenakan kondisi nyeri leher, yang paling sering adalah deep cervical flexor. Tindakan utama dari deep cervical flexor yang membantu gerakan segmen adalah fleksi craniocervical. Oleh karena itu, latihan fleksi craniocervical direkomendasikan untuk kondisi nyeri leher (Gupta et al., 2013).

Strengthening deep flexor neck adalah latihan yg dilakukan untuk mengaktivasi otot deep flexor neck, sehingga memberikan efek penurunan nyeri leher dan menurunkan disabilitas nyeri leher (Kage et al., 2016). Latihan ini dilakukan dengan mendorong kepala kearah belakang dengan menjaga posisi kepala tetap lurus dan diberikan berupa tahanan hingga waktu yang sudah ditentukan. Beberapa literasi menyebutkan latihan ini adalah latihan chin tuck. Dalam beberapa sumber yang penulis dapatkan latihan ini menggunakan beban yang ringan seperti penerapan konsep latihan isometrik, beban yang digunakan berbagai macam oleh peneliti, seperti dengan menggunakan tangan terapis, buku, tensimeter dan lain-lain. Walaupun jenis beban yang digunakan berbeda-beda, namun dari sini penulis menyimpulkan bahwa penerapan latihan ini menggunakan prinsip latihan isometrik dan memiliki efek mengurangi nyeri di area leher.

Berdasarkan hasil review pada sembilan artikel, maka untuk melihat pengaruh dari pemberian latihan deep neck flexor muscle activation pada pasien dengan nyeri leher dapat dilihat melalui banyak hal seperti jenis kelamin, usia sampel, penyakit yang dialami, teknik latihan, durasi latihan, kombinasi latihan yang diberikan pada subjek penelitian, dan alat ukur yang dipakai.

Berdasarkan penelitian Borisut et al. (2013) populasi subjek yang dipakai yaitu wanita berusia 20-35 tahun, karena prevalensi nyeri leher lebih besar pada wanita daripada pria, dengan prevalensi $30 \%$ dari pria dan $43 \%$ wanita mengalami nyeri leher pada suatu waktu dalam hidup mereka, dan gejala menjadi kronis di antara $10 \%$ pria dan $17 \%$ wanita. Sedangkan pada kedelapan jurnal lainnya menggunakan subjek dengan jenis kelamin laki-laki dan perempuan.

Pada artikel Bobos et al. (2016) menggunakan subjek laki-laki dan perempuan berusia antara 18-65 tahun dan analisis deskriptif umur sampel pada masing-masing kelompok menunjukkan adanya homogenitas pada umur pasien. Selain itu, prevalensi wanita yang tinggi 
Apriliani Y; Pristianto A; Wijianto \& Wahyuni

Fisiomu.2021 Vol 2(3): 133-149

DOI: $10.23917 /$ fisiomu.v1i3.15194

dibandingkan dengan pria di setiap kelompok dalam hal kondisi nyeri leher tercermin dengan jelas dalam studi klinis ini yang mengkonfirmasi literatur internasional yang tersedia. Dalam artikel yang ditulis Suvarnnato et al. (2019) usia responden dalam penelitian yaitu dari 18-60 tahun direkrut untuk menggambarkan orang dewasa dengan usia pekerja, dan dalam penelitian Rajalaxmi et al. (2020) mengatakan bahwa prevalensi nyeri leher meningkat seiring bertambahnya usia. Prevalensi nyeri leher yang lebih tinggi pada orang tua dan wanita menunjukkan bahwa prognosis nyeri leher bervariasi menurut usia dan jenis kelamin. Namun, tidak terdapat perbedaan pada hasil penelitian terkait usia maupun jenis kelamin pada semua artikel. Sehingga pengaruh aktivasi deep neck flexor tetap efektif dalam mengurangi nyeri leher.

Dari kondisi nyeri leher, pada artikel terbagi menjadi empat dengan kondisi chronic neck pain, dan lima artikel dengan chronic non specific neck pain. Latihan aktivasi otot deep cervical dilakukan dengan posisi yang bervariasi

1. Penelitian (Borisut et al., 2013) memiliki nilai hasil Pedro 8/10. Latihan fleksi kranioservikal terdiri dari latihan beban untuk otot fleksor kranio-serviks. Subyek berbaring terlentang dan perlahan-lahan menggerakkan kepala ke bagian dalam rentang fleksi kranio-servikal, dipandu oleh umpan balik dari sensor tekanan berisi udara yang ditempatkan suboksipital di belakang leher dan meningkat hingga tekanan dasar 20 mmHg. Subyek menggerakkan kepala untuk meningkatkan tekanan antara 22 sampai $30 \mathrm{mmHg}$; dan mempertahankan posisi ini untuk 10 detik dalam 15 pengulangan. Subyek mempertahankan kontraksi 10 detik tanpa rasa sakit. Istirahat sepuluh detik diperbolehkan di antara setiap kontraksi. Target dari latihan ini adalah fleksor dalam dari daerah serviks bagian atas, longus capitis dan colli, daripada fleksor superfisial, yang melenturkan leher tetapi bukan kepala.

2. Penelitian (Khan et al., 2014) nilai Pedro 7/10. Pasien dinstruksikan untuk melakukan latihan dalam posisi duduk tetapi mereka diizinkan untuk melakukan latihan dalam posisi terlentang dan tengkurap jika bermasalah dengan posisi duduk. Kelompok latihan isometrik melakukan latihan isometrik menggunakan theraband menargetkan fleksor leher, ekstensor dan rotator. Setiap latihan dilakukan 20 repetisi 3 kali seminggu selama 12 minggu.

3. Penelitian (Lee \& Kim, 2016) dengan nilai hasil Pedro 9/10. Pasien diposisikan terlentang, dengan lutut ditekuk dan dengan unit biofeedback tekanan (PBU) ditempatkan suboksipital, untuk mendeteksi peningkatan tekanan yang ditimbulkan oleh gerakan anggukan lembut dari fleksi kranioservikal. Umpan balik visual dari tingkat tekanan disediakan. Pasien 
Apriliani Y; Pristianto A; Wijianto \& Wahyuni Fisiomu.2021 Vol 2(3): 133-149

DOI: $10.23917 /$ fisiomu.v1i3.15194

diinstruksikan bagaimana melakukan fleksi kranioservikal dan mempraktikkan penargetan progresif pada lima tingkat tambahan (kenaikan $2 \mathrm{mmHg}$ ) antara 22 dan $30 \mathrm{mmHg}$ 24). Kontraksi isometrik dilakukan selama 10 detik, diikuti oleh 5 detik istirahat dalam 10 pengulangan.

4. Penelitian (Bobos et al., 2016) 7/10 fleksi kranioservikal dengan biofeedback tekanan udara, pasien mengangguk dari posisi terlentang, mengangguk dari posisi pronasi,dan mengangguk dari posisi duduk dekat dinding. Semua latihan dihentikan jika pasien mengaktifkan otot leher superfisial

5. Penelitian (Izquierdo et al., 2016) 10/10 Pelatihan fleksi kranio-servikal. Awalnya, pasien diajari untuk melakukan gerakan $\mathrm{CCF}$ secara perlahan dan secara terkendali dalam posisi terlentang, dengan kepala dan leher dalam posisi netral. Setelah gerakan $\mathrm{CCF}$ yang benar tercapai, subjek mulai menahan rentang CCF yang semakin meningkat menggunakan umpan balik dari sensor tekanan berisi udara yang ditempatkan di belakang leher. Pasien awalnya dilakukan CCF untuk secara berurutan mencapai 5 target tekanan dalam $2 \mathrm{mmHg}$ meningkat dari awal $20 \mathrm{mmHg}$ ke tingkat akhir 30 $\mathrm{mmHg}$. Fisioterapis mengidentifikasi tingkat target yang pasien dapat bertahan dengan mantap selama 5 detik tanpa menggunakan retraksi, tanpa penggunaan dominan otot fleksor leher superfisial, dan tanpa gerakan fleksi kranio-serviks yang cepat dan tersentak-sentak. Pelatihan dimulai pada tingkat sasaran ini. Untuk setiap level target, durasi kontraksi adalah meningkat menjadi 10 detik, dan subjek dilatih untuk melakukan 10 pengulangan dengan periode istirahat singkat antara setiap kontraksi (3-5 detik). Sekali satu set 10 pengulangan 10 detik dicapai pada satu level target, latihan dikembangkan untuk melatih pada tingkat target berikutnya hingga target akhir 10 pengulangan 10 detik pada $30 \mathrm{mmHg}$.

6. Penelitian (Ghaderi et al., 2016) 6/10 Latihan stabilisasi menargetkan otot fleksor dalam leher daripada otot fleksor superfisial yang menekankan Fleksi Craniocervical (CCF). Pada fase pertama pelatihan, fisioterapis meminta subjek untuk melakukan tes CCF rendah dan terkontrol dalam posisi terlentang menggunakan biofeedback tekanan. Subjek awalnya melakukan tes CCF untuk secara berurutan mencapai 5 dari garis dasar $20 \mathrm{mmHg}$ hingga tingkat akhir $30 \mathrm{mmHg}$. Fisioterapis mengontrol subjek untuk tidak menggunakan otot leher superfisial dan mengidentifikasi tingkat target yang dapat dilakukan subjek dengan benar. Selama 10 minggu pelatihan, latihan dilakukan di posisi yang berbeda untuk mencapai tingkat akhir pelatihan CCF.

7. Penelitian (Chung \& Jeong, 2018) 8/10 Pasien untuk melakukan gerakan lambat dan 
Apriliani Y; Pristianto A; Wijianto \& Wahyuni Fisiomu.2021 Vol 2(3): 133-149

DOI: $10.23917 /$ fisiomu.v1i3.15194

dikendalikan gerakan fleksi kranioservikal dalam posisi terlentang. Setelah gerakan fleksi kranioservikal yang benar-benar tercapai, pasien memulai fase kedua dari latihan di mana mereka untuk meningkatkan kemajuan-rentang fleksi kranioservikal yang meningkat secara menggunakan umpan balik dari sensor tekanan berisi udara (Biofeedback Tekanan Stabilizer, Grup ChattanoogaInc., USA) ditempatkan di belakang leher. Umpan balik sensor menampilkan jumlah perubahan tekanan sebagai lordosis servikal semakin rata selama fleksi kranioservikal. Pasien awalnya melakukan fleksi kranioservikal untuk mencapai 5 tekanan secara berurutan, dalam peningkatan $2 \mathrm{mmHg}$, dari garis dasar $20 \mathrm{~mm}$ $\mathrm{Hg}$ ke tingkat akhir $30 \mathrm{~mm} \mathrm{Hg}$.

8. Penelitian (Suvarnnato et al., 2019) nilai pedro 9/10 Latihan fleksor serviks dalam adalah latihan beban rendah yang berfokus pada otot fleksor serviks dalam. Latihan ini menargetkan otot fleksor dalam servikal daerah, bukan otot fleksor superfisial. Dalam penelitian ini, pelatihan fleksor serviks dalam dilakukan dalam posisi terlentang di atas meja eksperimen. Setiap peserta diminta untuk menggerakkan kepala mereka perlahan ke kisaran dalam seolah-olah mengatakan, "Ya". Untuk memperbaiki teknik latihan individu, peserta dipandu dalam gerakan mereka dengan umpan balik dari sensor tekanan berisi udara, yang ditempatkan di daerah suboksipital, yaitu leher posterior. Dasar dari sensor tekanan diatur ke inflasi $20 \mathrm{mmHg}$. Subyek adalah dipandu oleh peneliti untuk membiasakan mereka dengan latihan fleksor serviks dalam. Latihan fleksor serviks dalam prosedur itu benar bila dilakukan tanpa kontraksi otot-otot fleksor leher superfisial. Tindakan dangkal otot leher dipantau dengan palpasi peneliti. Lanjut, peserta dinilai secara individual untuk kemampuan mereka untuk melakukan latihan fleksor servikal dalam dengan benar tanpa provokasi nyeri leher. Penilaian ini dilakukan pada tingkat tekanan tambahan tertinggi yang sesuai untuk appropriate setiap individu

9. Penelitian (Rajalaxmi et al., 2020) nilai Pedro 8/10. Awalnya, pasien diajari untuk melakukan gerakan Cranio Cervical Flexion secara perlahan dan terkontrol dengan posisi terlentang, dengan kepala dan leher dalam posisi netral. Setelah gerakan CCF yang benar tercapai, subjek mulai memegang rentang CCF yang semakin meningkat menggunakan feedback dari tekanan tensi yang ditempatkan di belakang leher. Pasien awalnya melakukan CCF untuk secara berurutan mencapai 5 target tekanan dengan peningkatan $2 \mathrm{mmHg}$ dari nilai dasar 20 $\mathrm{mmHg}$ ke level akhir $30 \mathrm{mmHg}$. Fisioterapis mengidentifikasi level target yang dapat ditahan pasien dengan mantap selama 5 detik tanpa perlu melakukan retraksi, tanpa 
Apriliani Y; Pristianto A; Wijianto \& Wahyuni

Fisiomu.2021 Vol 2(3): 133-149

DOI: $10.23917 /$ fisiomu.v1i3.15194

penggunaan dominan otot fleksor leher superfisial, dan tanpa gerakan fleksi cranioservikal yang tersentak-sentak. Pelatihan dimulai pada tingkat target ini. Untuk setiap level target, durasi kontraksi ditingkatkan menjadi 10 detik, dan subjek dilatih untuk melakukan 10 repetisi dengan waktu istirahat singkat di antara setiap kontraksi(35 detik).

Latihan deep neck flexor dibandingkan dengan beberapa latihan ataupun kelompok kontrol tanpa intervensi. Latihan pembanding tersebut yaitu kelompok kontrol, general neck exercise, propioceptive training, routine exercise group, neck isometric exercise, dan neck stability. Pada pengukuran, alat ukur yang digunakan dalam sembilan artikel dalam pengukuran nyeri, tujuh menggunakan VAS, kecuali dua artike. Pertama artikel Bobos et al. (2016) menggunakan NPRS (Numeric pain rating scale), dan yang kedua Suvarnnato et al. (2019) menggunakan NPS (Nurmeric Pain Scale). VAS banyak digunakan pada artikel karena skala analog visual telah dipelajari terutama dalam kaitannya dengan pengobatan farmakologis nyeri. Ini dianggap sebagai salah satu metode terbaik untuk memperkirakan nyeri. VAS memiliki tingkat sensitivitas dan kapasitas diskriminasi yang tinggi dibandingkan dengan skala lain (Rajalaxmi et al., 2020).

Dalam membahas nyeri, kesembilan studi menyelidiki efek pengaruh latihan deep neck flexion activation dalam penurunan nyeri leher, kesembilan studi tersebut menemukan bahwa latihan deep neck flexion efektif dalam penurunan nyeri leher. Seperti pada penelitian Khan et al. (2014), studi ini mengevaluasi efek dari latihan leher isometrik dan general neck exercise dalam pengelolaan nyeri leher nonspesifik kronis. Kedua intervensi tersebut secara signifikan menurunkan nyeri leher, memperbaiki fungsi leher, dan meningkatkan rentang gerakan leher setelah 12 minggu intervensi. Dalam penelitian ini subjek mengikuti hanya selama 12 minggu, hasil yang dilaporkan menunjukkan bahwa program pelatihan dan 10-15 pengulangan latihan cukup untuk mencapai perubahan neuromuskuler dan fisiologis terkait dengan penurunan nyeri otot.

Menurut Lee \& Kim, (2016) pelatihan Deep cervical flexion (DCF) efektif dalam meningkatkan fungsi leher, dibandingkan dengan self-exercise pada pasien dengan chronic non-specific neck pain. Selain itu, manipulasi toraks dikombinasikan dengan pelatihan $\mathrm{DCF}$ menghasilkan pengurangan nyeri yang lebih besar, peningkatan kekuatan dan daya tahan otot, ROM, dan NDI, dibandingkan olahraga saja pada pasien dengan nyeri leher kronis. Beberapa penelitian telah mengidentifikasi gangguan aktivasi cervical flexor muscles, longus colli dan longus capitis pada pasien dengan CNP. Mengingat peran cervical flexor muscles dalam penyangga postural, penurunan kemampuan untuk mempertahankan postur tegak dari tulang belakang leher dapat dianggap sebagai ukuran 
Apriliani Y; Pristianto A; Wijianto \& Wahyuni

Fisiomu.2021 Vol 2(3): 133-149

DOI: $10.23917 /$ fisiomu.v1i3.15194

penurunan otot pendukung postural selama tugas fungsional. Penurunan aktivasi cervical flexor muscles telah dikaitkan dengan posisi forward head dalam penelitian sebelumnya. Dalam artikel oleh Chung \& Jeong, (2018) mengatakan bahwa studi terbaru menunjukkan bahwa isometrik (NIE) serta latihan dinamis telah terbukti meningkatkan nyeri leher dan kecacatan, bila latihan dilakukan dengan perkembangan atau intensitas tinggi.

Pada artikel Izquierdo et al. (2016) intervensi CCF training dan propioceptive training menghasilkan pengurangan nyeri dan kecacatan, yang menegaskan sifat modulasi nyeri dari senam leher aktif dan menyoroti pentingnya olah raga sebagai komponen pengobatan untuk manajemen pasien dengan nyeri leher kronis. Dan dalam Ghaderi et al. (2016) menunjukkan penurunan yang signifikan dari nyeri leher dan kecacatan yang dirasakan sama pada kedua kelompok latihan tanpa perbedaan yang signifikan antara dua kelompok. Maka penelitian memberikan bukti lebih lanjut bahwa latihan stabilisasi dan latihan rutin dapat menghasilkan perbaikan gejala klinis pada pasien yang menderita nyeri servikal.

Dalam penelitian ini peneliti masih memiliki banyak keterbatasan, terdapat beberapa hal yang membatasi penelitian di antaranya keterbatasan artikel dan keterbatasan penulis:

1. Pada artikel Rajalaxmi et al. (2020) tidak menjabarkan karakteristik populasi sampel kriteria inklusi dan eksklusi pengambilan subjek penelitian.

2. Dari kesembilan artikel, terdapat tiga artikel yang tidak mencantumkan usia pada subjek penelitian.

3. Penelitian ini tidak dilakukan pada pasien nyeri leher dengan riwayat cedera maupun operasi leher

4. Kelemahan penelitian ini menggunakan usia rentan sangat jauh 18-65 tahun sehingga dikhawatirkan memiliki waktu recovery dan hasil yang berbeda pada subjek di lapangan

5. Sulit menemukan artikel dengan metode RCT dan teridentifikasi dalam Scimago Journal Country Rank (SJR).

\section{Kesimpulan dan Saran}

Berdasarkan hasil studi dengan menggunakan metode critical review terhadap kesembilan artikel terpilih, yang dijadikan landasan dalam studi penelitian ini bahwa keseluruhan penelitian menunjukkan adanya pengaruh yang signifikan pada latihan deep neck flexor muscle activation yang terdiri dari craniocervical flexion dan cervical stabilizating exercise terhadap penurunan nyeri leher pada kondisi nyeri leher.

Responden yang digunakan untuk latihan ini idealnya pada usia 18-65 tahun. Beberapa latihan dikombinasikan dengan grup kontrol, general neck exercise, propioceptive training, routine exercise, neck isometric exercise dan neck stability. Latihan dilakukan 
Apriliani Y; Pristianto A; Wijianto \& Wahyuni

Fisiomu.2021 Vol 2(3): 133-149

DOI: $10.23917 /$ fisiomu.v1i3.15194

selama 12 minggu, selama 30-40 menit per sesi selama 3 kali seminggu. Hasilnya lebih bagus dibandingkan dengan latihan self-exercise. Sehingga latihan aktivasi otot fleksor bagian dalam efektif digunakan baik dengan pasien nyeri leher kronis ataupun nyeri leher kronis non spesifik.

Bagi studi selanjutnya dalam penelitian ini akan lebih baik jika menggunakan rentan usia yang tidak terlalu jauh, rekomendasi bagi peneliti selanjutnya agar dapat mempertimbangkan usia yang digunakan untuk pasien nyeri leher. Hasil studi ini semoga dapat bermanfaat dan dapat dijadikan referensi dan menambah wawasan dalam pemberian latihan deep neck flexor muscle activation terhadap penurunan nyeri leher.

\section{Ucapan Terimakasih}

Terimakasih saya ucapkan untuk dorongan dan dukungan orangtua dan teman teman saya, serta terimakasih karena penelitian ini dapat diselesaikan tidak lepas dari bimbingan dosen pembimbing saya bapak Arif Pristianto, dan para penguji di sidang skripsi saya bapak Wijianto, beserta ibu Wahyuni.

\section{Daftar Pustaka}

Bobos, P., Billis, E., Papanikolaou, D. T., Koutsojannis, C., \& Macdermid, J. C. (2016). Does Deep Cervical Flexor Muscle Training Affect Pain Pressure Thresholds of Myofascial Trigger Points in Patients with Chronic Neck Pain? A Prospective Randomized Controlled Trial. Rehabilitation Research and Practice, 2016.

https://doi.org/10.1155/2016/6480826

Borisut, S., Vongsirinavarat, M., Vachalathiti, R., \& Sakulsriprasert, P. (2013). Effects of strength and endurance training of superficial and deep neck muscles on muscle activities and pain levels of females with chronic neck pain. Journal of Physical Therapy Science, 25(9), 1157-1162. https://doi.org/10.1589/jpts.25.1157

Cheung, J., Kajaks, T., \& MacDermid, J. C. (2013). The Relationship Between Neck Pain and Physical Activity. The Open Orthopaedics Journal, 7(1), 521-529. https://doi.org/10.2174/1874325001307010 521

Chung, S., \& Jeong, Y. G. (2018). Effects of the craniocervical flexion and isometric neck exercise compared in patients with chronic neck pain: A randomized controlled trial. Physiotherapy Theory and Practice, 34(12), 916-925. https://doi.org/10.1080/09593985.2018.143 0876

Ghaderi, F., Jafarabadi, M. A., \& Javanshir, K. (2016). The clinical and EMG assessment of the effects of stabilization exercise on nonspecific chronic neck pain: A randomized controlled trial. Journal of Back and Musculoskeletal Rehabilitation, 
Apriliani Y; Pristianto A; Wijianto \& Wahyuni

Fisiomu.2021 Vol 2(3): 133-149

DOI: $10.23917 /$ fisiomu.v1i3.15194

$30(2)$,

211-219.

https://doi.org/10.3233/BMR-160735

Hande, D., \& Agrawal, Y. K. (2017).

International Journal of Multidisciplinary

Research and Development Effect of activation of deep neck flexor muscle exercise on neck pain due to smartphone addiction. Issue, 4(7), 489-492. www.allsubjectjournal.com

Izquierdo, T. G., Pecos-Martin, D., Lluch Girbés, E., Plaza-Manzano, G., Rodríguez Caldentey, R., Mayor Melús, R., Blanco Mariscal, D., \& Falla, D. (2016). Comparison of cranio-cervical flexion training versus cervical proprioception training in patients with chronic neck pain: A randomized controlled clinical trial. Journal of Rehabilitation Medicine, 48(1), 48-55. https://doi.org/10.2340/165019772034

Jull, G. A., Falla, D., Vicenzino, B., \& Hodges, P. W. (2009). The effect of therapeutic exercise on activation of the deep cervical flexor muscles in people with chronic neck pain. Manual Therapy, 14(6), 696-701. https://doi.org/10.1016/j.math.2009.05.004

Khan, M., Soomro, R. R., \& Ali, S. S. (2014). The effectiveness of isometric exercises as compared to general exercises in the management of chronic non-specific neck pain. Pakistan Journal of Pharmaceutical Sciences, 27(5), 1719-1722.

Kim, Jin Young \& Kwag, K. il. (2016). 2016 July $31^{\text {th }}, 2021$ on $z$ oom cloud meeting Muhammadiyah University of Surakarta, Central Java, Indonesia
Kim Cervical fleor with neck pain. Journal of Physical Therapy, 2016(28), 269-273.

Lee, K. W., \& Kim, W. H. (2016). Effect of thoracic manipulation and deep craniocervical flexor training on pain, mobility, strength, and disability of the neck of patients with chronic nonspecific neck pain: A randomized clinical trial. Journal of Physical Therapy Science, $28(1)$, $175-180$. https://doi.org/10.1589/jpts.28.175

Prasana, I. G. E. J., Adiputra, I. N., \& Dinata., I. M. K. (2018). Original article. 6(1), 25-28. Rajalaxmi, V., Manickam, M., Srilakshmi, M., Arunselvi, J., Jayabarathi, R., Anupreethi, P., \& Sujatha, K. (2020). The role of multistep core stability exercise with and without conventional neck exercises in the treatment of chronic non-specific neck pain a randomized controlled trial. Biomedicine (India), 40(2), 232-235.

Suvarnnato, T., Puntumetakul, R., Uthaikhup, S., \& Boucaut, R. (2019). Effect of specific deep cervical muscle exercises on functional disability, pain intensity, craniovertebral angle, and neck-muscle strength in chronic mechanical neck pain: A randomized controlled trial. Journal of Pain Research, 12, 915-925. https://doi.org/10.2147/JPR.S190125

Thoomes-De Graaf, M., \& Schmi, M. A. (2012). The effect of training the deep cervical flexors on neck pain, neck mobility, and 
Apriliani Y; Pristianto A; Wijianto \& Wahyuni Fisiomu.2021 Vol 2(3): 133-149 DOI: $10.23917 /$ fisiomu.v1i3.15194

dizziness in a patient with chronic nonspecific neck pain after prolonged bed rest: A case report. Journal of Orthopaedic and Sports Physical Therapy, 42(10), 853860.

https://doi.org/10.2519/jospt.2012.4056

Yuliana, E., \& Kushartanti, B. M. W. (2019). Manipulasi Topurak (Totok, Pukul, Gerak)
Untuk Penyembuhan Nyeri Dan Ketegangan Otot Leher. Medikora, 17(2), 113-119.

https://doi.org/10.21831/medikora.v17i2.29 182 